Indonesian Journal of
Mathematics and Natural Sciences Education
p-ISSN: 2721-172X e-ISN: 2721-1746
Vol. 1 No.3 Th 2020; hal 150-157
http://mass.iain-jember.ac.id

\title{
Peranan Media Pembelajaran Berbasis Android Ditinjau dari Kepribadian Peserta Didik
}

\author{
Yuli Ismi Nahdiyati Ilmi1 ${ }^{1}{ }^{*}$, Gusti Firda Kahirunnisa ${ }^{1}$ \\ ${ }^{1}$ Prodi Pendidikan Matematika Universitas Islam Malang, Malang, Indonesia. \\ *E-mail: yuliismi.ni@unisma.ac.id
}

\begin{abstract}
Abstrak
Penelitian ini bertujuan untuk mengkaji beberapa sumber pustaka yaitu mengenai peran media pembelajaran berbasis android pada peserta didik apabila ditinjau dari kepribadiannya. Hasil dari penelitian ini akan dijadikan sebagai bahan pustaka utama dalam pelaksanaan penelitian berikutnya yaitu mengenai peran media pembelajaran berbasis android pada peserta didik ditinjau dari kepribadian. Penelitian ini khusus membicarakan tipe kepribadian menurut Carl Gustav Jung yang membedakan dua tipe kepribadian yaitu, tipe kepribadian introvesi (introvert) dan ekstraversi (extrovert). Jenis penelitian ini yaitu studi literatur, adapun langkah-langkah dalam penelitian ini, yaitu (1) mengumpulkan sumber pustaka sesuai dengan penelitian ini dengan melakukan review pada istilah penting yang digunakan dalam penelitian, (2) mengumpulkan sumber pustaka pada hasil penelitian yang relevan, hal ini bertujuan agar memperkaya proses analisis, sehingga hasil analisis dapat menyimpulkan hasil yang objektif, (3) langkah berikutnya, yaitu melakukan analisis secara mendalam terhadap semua sumber pustaka yang telah dikumpulkan dengan dilanjutkan menyusun pembahasan, kemudian, setelah melakukan pembahasan, (4) mengambil kesimpulan dari hasil analisis, (5) berikutnya, yaitu memberikan pengajuan saran berdasarkan temuan-temuan yang diperoleh. Hasil penelitian studi literatur ini menunjukkan bahwa peranan media pembelajaran berbasis android ditinjau melalui kepribadian siswa memiliki peranan dalam pembelajaran yang lebih efektif dan menyenangkan, serta tepat sasaran sesuai dengan karakteristik kepribadian peserta didik.
\end{abstract}

Kata Kunci: android, kepribadian, media pembelajaran, prestasi belajar.

\section{PENDAHULUAN}

Permulaan pembelajaran di tahun 2020 ini menjadi tantangan besar bagi pendidik dan peserta didik untuk memulainya. Hal tersebut diakibatkan virus corona yang menjangkiti hampir seluruh negara, salah satunya yaitu Indonesia yang sampai saat ini masih mengalami peningkatan pasien terkonfirmasi positif covid-19
(@BNPB_Indonesia). Syah (2020) menyatakan bahwa pendidikan pada masa pendemi covid-19 merupakan salah satu sektor yang paling terdampak dalam kehidupan saat ini. Pembelajaran jarak jauh menjadi pilihan utama dan saran dari pejabat Kesehatan untuk mengurangi penularan virus yang mirip dengan flu ini. Walaupun perintah protokol kesehatan agar selalu menjaga jarak minimal satu meter, 
menggunakan masker, dan sering cuci tangan atau menggunakan handsanitizer, penularan yang sangat cepat menambah kasus yang terdampak positif di Indonesia. Berdasarkan data dari situs UNESCO dikemukakan bahwa 577 juta pelajar di dunia terancam terkena pandemi ini.

Oleh karena itu, pembelajaran online sangat dibutuhkan untuk mendukung tetap berjalannya proses belajar mengajar. Chakraborty and Muyia (2014) mengatakan bahwa pembalajaran online menciptakan pembelajaran yang menarik, Adapun faktor untuk mencapai itu yaitu, menciptakan dan memelihara lingkungan belajar yang positif, membangun komunitas belajar, memberikan umpan balik yang konsisten secara tepat waktu, dan menggunakan teknologi yang tepat untuk mengirim konten yang tepat. Penggunaan media sangat bermanfaat sebelumnya walaupun tidak melalui pembelajaran dalam jaringan. Sebaliknya, pada musim pandemi seperti saat ini aplikasiaplikasi pendukung pembelajaran dalam jaringan sangat diperlukan, misalnya saja yaitu penggunaan zoom, google meet, Edmodo, serta aplikasi lain untuk memenuhi tujuan pembelajaran dalam Pendidikan. Hal tersebut menunjang pendidik sebagai perantara dalam menyampaikan media pembelajaran yang telah dibuat oleh pendidik melalui aplikasi pembelajaran dalam jaringan.

Selain menggunakan aplikasi tatap maya yang telah disebutkan di atas, kita perlu juga menggunakan media pembelajaran untuk membantu pembelajaran di sekolah ataupun dalam perguruan tinggi. Media pembelajaran sangat bermanfaat dalam pembelajaran khususnya dalam masa sulit seperti ini, yang mana peserta didik dan pendidik tidak diperbolehkan untuk tatap muka. Seperti pada penelitian Eyler dan Giles (1994) membuktikan bahwa keefektifan pembelajaran dipengaruhi oleh media yang digunakan pendidik, yakni pembelajaran yang terlibat langsung dengan pengalaman-pengalaman belajar yang melibatkan simbol-simbol verbal melalui sajian teks. Tingkat abstraksi pada model pembelajaran ini sangat rendah sehingga memudahkan siswa dalam menyerap pengetahuan dan keterampilan baru.

Teknologi Informasi dan Komunikasi (TIK) tidak hanya berfungsi sebagi pengolah data saja, namun teknologi dapat digunakan sebagai media pembelajaran. Means (1993) menerangkan bahwa kebutuhan masyarakat persekolahan untuk memanfaatkan teknologi dalam pembelajaran merupakan bagian dari reformasi pembelajaran. Matematika merupakan salah satu bidang ilmu pengetahuan yang juga mengalami perubahan mengikuti perkembangan teknologi saat ini. Kehadiran suatu media berbantuan komputer atau handphone tidak diragukan lagi dalam penggunaan pembelajaran. Salah satu bagian matematika yang dapat dikembangkan pada penggunaan media yaitu pada geometri khususnya dimensi tiga. Adanya media memiliki arti yang sangat penting, karena pada proses pembelajaran penyampaian ketidakjelasan materi yang disampaikan dapat terbantu dengan kehadiran media sebagai perantara. Soekartiwi (2008) 
menyatakan ada beberapa keuntungan yang dapat diraih dengan menggunakan alat peraga atau media yaitu: "meningkatkan motivasi belajar peserta didik, mencegah kebosanan dalam mengikuti suatu proses belajar mengajar, dan menjadikan proses belajar mengajar berjalan lebih sistematis, dinamis, dan menarik".

Matematika merupakan salah satu pelajaran yang perlu media sebagai mediasi pemahaman antara pendidik dengan peserta didik. Terutama pada pembelajaran online tidak memungkiri, bahwa media pembelajaran terutama berbasis android sangat diperlukan. Karena matematika tidak hanya dijelaskan melalui lisan, namun juga harus ada pergerakan, seperti dengan tulisan tangan atau media yang mendukung pemahaman pelajar. Khususnya pada bidang geometri, media sangat membantu agar pembelajaran lebih efisien, jelas, dan menarik. Seperti pada penelitian Faudiyah (2012) menyatakan bahwa peserta didik mengalami kesulitan dalam memahami, membayangkan atau merealisasikan bangun-bangun ruang dalam dimensi tiga. Melalui media dalam proses pembelajaran menjadi salah satu upaya mengurangi kendala peserta didik serta menciptakan pembelajaran yang berkualitas dan bermakna.

Pendidik seharusnya turut memperhatikan kepribadian peserta didik untuk menunjang keberhasilan pembelajaran selama di kelas. Terkadang keberhasilan pembelajaran dapat menggunakan model-model pembelajaran yang diikuti dan berdasarkan karakteristik peserta didik pada saat di kelas. Walaupun, hanya sebentar bertatap muka, namun pendidik dapat menebak bagaimana kepribadian peserta didik agar menunjang keberhasilan pembelajaran. Perkembangan kepribadian adalah salah satu peristiwa psikis yang sangat penting. Kepribadian atau psyche adalah mencakup keseluruhan fikiran, perasaan, dan tingkah laku, kesadaran dan ketidaksadaran. Kepribadian membimbing orang untuk menyesuaikan diri dengan lingkungas sosial dan lingkungan fisik (Alwisol, 2009).

Ada dua aspek kepribadian yang beroperasi di tingkat sadar dan tak sadar, yakni attitude (introversionexstraversion) dan function (thinking, feeling, sensing, dan intuiting). Peneliti hanya berfokus pada attitude, karena sikap atau attitude lebih mudah diamati pada peserta didik selama pembelajaran ataupun pada saat di luar pembelajaran, semisal pada saat mereka istirahat. Menurut Alwisol (2009) sikap introversi mengarahkan pribadi ke pengalaman subjektif, memusatkan diri pada dunia dalam dan privat di mana realita hadir dalam bentuk hasil amatan, cenderung menyendiri, pendiam/tidak ramah, bahkan antisosial. Sedangkan sikap ektraversi mengarahkan pribadi ke pengalaman obyektif, memusatkan perhatiannya ke dunia luar alih-alih berfikir mengenai persepsinya, cenderung berinteraksi dengan orang disekitarnya, aktif, dan ramah.

Penelitian yang mengaitkan pembelajaran matematika dan kepribadian, salah satunya yaitu oleh Sumantri dan Pratiwi (2014) yang membicarakan efek media pembelajaran dan tipe kepribadian pada peserta didik SD dalam 
kemampuan matematika. Mereka menyimpukan bahwa media pembelajaran interaktif lebih berpengaruh pada peserta didik yang bertipe kepribadian introvert. Selain itu, Batubara (2017) turut meneliti keefektifan produk media pembelajaran berbasis android bahwa produk tersebut mendapatkan tanggapan positif oleh peserta didik.

Tujuan dari penelitian ini yaitu peran media pembelajaran berbasis android pada peserta didik apabila ditinjau dari kepribadiannya. Disini peneliti khusus membicarakan tipe kepribadian menurut Carl Gustav Jung yang membedakan dua tipe kepribadian yaitu, tipe kepribadian introvesi (introvert) dan ekstraversi (extrovert).

\section{METODE}

Jenis penelitian ini merupakan jenis penelitian studi literatur. Adapun langkah-langkah dalam penelitian ini, yaitu (a) mengumpulkan literatur sesuai dengan penelitian ini dengan melakukan review pada istilah penting yang digunakan dalam penelitian. Beberapa literatur besumber dari berbagai referensi mulai dari buku dan artikel yang berkaitan dengan penelitian ini. Adapun istilah penting yang digunakan, yaitu peran media pembelajaran pada matematika dan pembelajaran berdasarkan kepribadian khususnya bagi peserta didik introvert dan extrovert, (b) mengumpulkan literatur pada hasil penelitian yang relevan, hal ini bertujuan agar memperkaya proses analisis, sehingga hasil analisis dapat menyimpulkan hasil yang objektif, (c) langkah berikutnya, yaitu melakukan analisis secara mendalam terhadap semua literatur yang telah dikumpulkan dengan dilanjutkan menyusun pembahasan. Pembahasan ini dirancang untuk menyimpulkan terkait peran media pembelajaran berbasis android pada peserta didik dengan kepribadian introvert dan extrovert, (d) kemudian, setelah melakukan pembahasan, selanjutnya yaitu mengambil kesimpulan dari hasil analisis. Kesimpulan yang diperoleh harus sesuai dengan pernyataan tujuan semula dari penlitian ini, (e) berikutnya, yaitu memberikan pengajuan saran berdasarkan temuantemuan yang diperoleh. Temuantemuan yang diperoleh dapat dijadikan masukan agar bermanfaat bagi peneliti dan pembaca untuk melanjutkan penelitian lanjutan. Temuan penlitian ini tentunya bersarkan hasil analisis dengan literatur-literatur yang telah di review dan hasil penelitian yang relevan dengan penelitian ini, yaitu peran media pembelajaran berbasis android ditinjau dari kepribadian peserta didik.

\section{HASIL DAN PEMBAHASAN}

\section{Hasil Penelitian}

Berdasarkan tahapan dalam metode penelitian di atas, hasil penelitian yang diperoleh setelah mereview, yaitu (a) pengumpulan sumber pustaka telah dilaksanakan dengan tertulis pada daftar Pustaka. Sumber pustaka tersebut telah dilaksanakan review pada beberapa istilah penting yang dapat dilihat pada pendahuluan, (b) beberapa hasil review sumber pustaka hasil penelitian yang relevan dengan penelitian, yakni (1) penelitian yang dilakukan oleh Sumantri dan Pratiwi (2015) yang berjudul, "The 
Effect of Learning Media and Types of Personality on Elementary Student's Mathematic Performance". Pada penelitian tersebut menggunakan metode penelitian analisis variansi (ANNOVA) menghasilkan bahwa kemampuan matematika pada kelompok siswa yang menggunakan multimedia interaktif lebih tinggi daripada menggunakan papan magnet (magneting board), efek media pembelajaran dan tipe kepribadian pada kemampuan matematika, khususnya untuk anak yang introvert kemampuan matematika dengan menggunakan multimedia interaktif lebih efektif daripada menggunakan media papan magnetic, kemudian untuk anak extrovert penggunaan media papan magnetic menghasilkan kemampuan matematika yang lebih baik daripada penggunaan pembelajran multimedia interaktif. Berdasarkan hasil saran penelitian ternyata anak yang extrovert dapat ditingkatkan kembali keefektifan media pembelajaran multimedia interaktif dengan memberikan media pembelajaran yang lebih interaktif dengan mengaktifkan system Kerjasama antar teman, atau biasanya dengan penggunaan aplikasi media berbasis game.

Penelitian yang lain terkait pembelajaran media pembelajaran berbasis android yaitu oleh Batubara (2017) menghasilkan bahwa media pembelajaran matematika berbasis android diperoleh dari hasil reviewer, peer reviewer, dan guru SD/MI memperoleh skor 434 dan persentase $86,7 \%$ yang mengartikan sangat baik, kemudian respon dari subjek penelitian sendiri memperoleh skor 439 dengan persentase $87,8 \%$. Sehingga dapat disimpulkan produk media pembelajaran pada penelitian tersebut dapat digunakan dan efektif. Selain itu peneliti sendiri juga telah malakukan penelitian pengembangan media pembelajaran berbasis android pada materi dimensi tiga. Hasil penelitian juga menunjukkan bahwa media yang digunakan efektif dengan persentase pada ahli praktisi menunjukkan prosentase $75 \%$ serta validator ahli media yaitu $93 \%$ yang berarti media valid dan layak digunakan. Untuk analisis data telaah praktisi yang dilakukan oleh guru SMA Islam Nusantara kelas XII mencapai prosentase $84 \%$, dengan berarti keseluruhan media pembelajaran valid dan layak digunakan. Kemudian uji coba pada user yaitu siswa kelas XII SMA Islam Nusantara diperoleh prosentase sebesar 91,3\% yang menyatakan kriteria media pembelajaran valid dan layak digunakan.

\section{Pembahasan}

Berdasarkan kondisi saat ini yaitu pada musim pandemi virus covid-19, persiapan pembelajaran daring menjadi pembelajaran utama oleh peserta didik. Matematika merupakan pembelajaran yang akan sulit dipahami jika hanya melalui aplikasi virtual, oleh karena itu perlu adanya media pembelajaran berbasis android terutama pada materi yang membutuhkan gambar seperti materi geometri. Selain itu, terkadang pendidik hanya memperhatikan input dan output selama pembelajaran. Sehingga akan sulit mengetahui karakter siswa agar pendidik tepat memilih metode pembelajaran yang sesuai dengan karakteristik siswa. Potensi yang dimiliki siswa akan lebih mudah dilihat melalui 
kepribadian, apabila dibedakan menjadi dua yaitu tipe kepribadian introvert dan extrovert.

Komunikasi diperlukan pada pembelajaran di kelas agar mengetahui dan menganalisis kemampuan matematika peserta didik. Model pembelajaran yang tepat dapat diaplikasikan pada peserta didik dalam kelas $\mathrm{A}$, namun hal tersebut tidak tepat pada kelas lain. Penyebab ini dikarenakan setiap individu peserta didik memiliki keunikan tersendiri dan memiliki karakteristik yang berbeda. Perbedaan ini dapat diterima dan didayagunakan pada pembelajaran. Banyak faktor yang menyebabkan perbedaan, salah satunya yaitu kepribadian mereka. Salah satu penelitian berasal dari Awuondo, dkk (2019) melakukan penelitian pengaruh sifat kepribadian ekstrovert pada prestasi matematika. Penelitian tersebut menghasilkan terdapat korelasi positif yang berarti kepribadian mempengaruhi prestasi matematika.

Selain itu, berdasarkan pendahuluan di atas, juga terdapat penelitian dari Sumantri dan Pratiwi (2015) bahwa tipe kepribadian introvert dan extrovert mempengaruhi pembelajaran multimedia interaktif ataupun media papan magnetic. Penelitian tersebut menghasilkan 4 hal yaitu, (1) performa matematika pada kelompok siswa, menggunakan multimedia interaktif lebih tinggi daripada kelompok siswa yang menggunakan media papan magnetic, (2) terdapat efek interaksi yang signifikan media pembelajaran dan tipe kepribadian pada performa matematika siswa, (3) performa matematika pada Sebagian kelompok siswa introvert, penggunaan multimedia pembelajaran interaktif lebih tinggi daripada kelompok siswa introvert yang menggunakan media papan magnetic, (4) performa matematika pada sebagian kelompok siswa extrovert penggunaan media papan magnetic lebih tinggi pada kelompok siswa extrovert yang menggunakan multimedia interaktif.

Multimedia interaktif ini misalkan saja pembelajaran berbasis android, banyak penelitian yang menunjukkan bahwa penggunaan telekomunikasi pintar ini memberikan manfaat dan efektif dalam pembelajaran, hal tersebut berdasarkan pada penelitian oleh Hendriawan, dkk (2018), Batubara (2017), Setyadi (2017). Mereka mengungkapkan bahwa pembelajaran berbasis android dapat memberikan motivasi pada siswa dalam berlatih kemampuan matematika, serta digunakan sebagai multimedia penunjang belajar untuk siswa yang dapat digunakan kapan pun dan dimana pun.

\section{SIMPULAN}

Berdasarkan hasil penelitian dan pembahasan di atas, dapat diperoleh kesimpulan bahwa peranan media pembelajaran berbasis android ditinjau melalui kepribadian siswa memiliki peranan dalam pembelajaran yang lebih efektif dan menyenangkan, serta tepat sasaran sesuai dengan karakteristik kepribadian peserta didik.

Adapun beberapa saran yang dapat diberikan dalam penelitian ini, yaitu karena pembelajaran berbasis android jarang dikaitkan dengan kepribadian siswa, maka perlu ada penelitian lanjutan mengenai pengembangan media pembelajaran berbasis 
android dengan disesuaikan karakter kepribadian siswa. Selain itu, pembelajaran menggunakan multimedia interaktif seperti berbasis android dapat dijadikan sebagai alternatif pembelajaran agar materi yang disampaikan tidak monoton dan siswa lebih tertarik khususnya pada pembelajaran matematika.

\section{DAFTAR PUSTAKA}

Alwisol. (2010). Psychology of Personality (Psikologi Kepribadian). Malang: UMM Press.

Awuondo, K. O., Aloka, P. J. O., \& Kiplagat, P. (2019). Influence Extrovert Personality Trait on Mathematics Achievement among Secondary School Students in Kenya. International Journal of Advanced and Multidisciplinary Social Science 2019; 5 (2): 21-25

Batubara, H. H. (2017). Pengembangan Media Pembe-lajaran Matematika berbasis Android untuk Siswa SD/MI. MUALLIMUNA: Jurnal Madrasah Ibtidaiyah, 3 (1), 12-27.

Chakraborty, M., \& Muyia Nafukho, F. (2014). Strengthening student engagement: what do students want in online courses?. European Journal of Training and Development, Vol. 38 No. 9, pp. 782-802.

Eyler \& Giles. (1994). The Theoritical Roots of Service-Learning in John Dewey: Toward a Theory of Service Learning, Vaderbilt University. Michigan Journal of Community Service Learning Fall 1994, Vol. 1, No. 1, pp. 77-85.
Faudiyah, Q. A. (2012). Pengembangan Media Pembelajaran Matematika Berbasis Komputer untuk Materi Dimensi 3 pada Pembelajaran Matematika SMA Kelas X. Skripsi. Malang: Universitas Negeri Malang.

Hendriawan, M. A., \& Guntur M. M. (2018). Pengembangan JIMATH Sebagai Multimedia Berbasis Android untuk Siswa Sekolah Menengah Atas. MaPan: Jurnal Matematika dan Pembelajaran volume 6 No 1, Juni.

Means, B. (1993). Using technology to support education reform. Amerika Serikat: US Government Printing Office.

Setyadi, D. (2017). Pengembangan Mobile Learning Berbasis Android Sebagai Sarana Berlatih Mengerjakan Soal Matematika. Jurnal Satya Widya. 33 (2): 87-92.

Soekartiwi. (2008). Rancangan Instruksional. Jakarta: PT. Raja Grafindo Persada.

Sumantri, M. S., \& Pratiwi, N. (2015). The Effect of Learning Media and Types of Personality on Elementary Student's Mathematic Performance. American Journal of Educational Research. 3 (3): 276-281. https://doi.org/10.12691/education3-3-4

Syah, R. H. (2020). Dampak Covid-19 pada Pendidikan di Indonesia: Sekolah, Keterampilan, dan Proses Pembelajaran. SALAM: Jurnal Sosial Dan Budaya Syar-I, 7 (5). https://doi.org/10.15408/sjsbs.v7i5. $\underline{15314}$ 


\section{PROFIL SINGKAT}

Penulis bernama Yuli Ismi Nahdiyati Ilmi ini lahir di kota Malang pada tanggal 16 Juli 1991. Penulis merupakan salah satu dosen di Universitas Islam Malang. Kuliah S1 juga di Universitas Islam Malang tahun Angkatan 2009, kemudian setelah lulus, satu tahun kemudian melanjutkan studi
S2 di Universitas Negeri Malang pada prodi Pendidikan matematika. Barubaru ini penulis tertarik dengan penelitian kaitan antara pembelajaran matematika dengan kepribadian peserta didik. Pada tahun sebelumnya penulis juga telah meneliti pengembangan media pembelajaran berbasis android pada materi dimensi tiga. 